\title{
Robert Kempa
}

Białystok

\section{Prusy Wschodnie w strategii militarnej Republiki Weimarskiej}

Zawarty przez Niemcy 11 listopada 1918 r. rozejm w Rethondes koło Compiegne nie zapowiadał klęski militarnej państwa niemieckiego. Oddziały niemieckie zmuszone zostały do wycofania się z okupowanych terytoriów Francji, Francji, Belgii, Luksemburga, Rosji oraz zdobytych w 1871 r. Alzacji i Lotaryngii ${ }^{1}$.

Całe terytorium Niemiec pozostawało jednak wolne od wojsk koalicyjnych. Zwłaszcza na wschodzie siły niemieckie okupowały obszar Inflant, Białorusi i Ukrainy. W tej sytuacji część dowódców i polityków widziała właśnie na wschodzie możliwość przejęcia inicjatywy i tym samym nakłonienia zwycięskich mocarstw zachodnich do „łagodniejszego” potraktowania Niemiec na konferencji pokojowej. Szczególne nadzieje dyplomacja niemiecka pokładała w USA i 14-punktowym planie pokojowym prezydenta W. Wilsona²

Kalkulacje te pokrzyżował już rozejm z Trewiru z 16 lutego 1919 r., na mocy którego cała granica polsko-niemiecka stała się dla wojsk niemieckich w praktyce nieprzekraczalna. Alternatywą było narażenie się na interwencję aliancką ${ }^{3}$.

Wszelkie nadzieje niemieckie prysły 7 maja 1919 roku. Wówczas to delegacja niemiecka odebrała w Paryżu warunki pokoju. W przedstawionej 29 maja odpowiedzi Niemcy skoncentrowały się na oprotestowaniu części postanowień terytorialnych, a zwłaszcza przebiegu granicy polsko-niemieckiej na obszarze Górnego Śląska i Prus Zachodnich. 28 czerwca w Wersalu podpisano ostateczny traktat pokojowy. Warunki rozbrojeniowe sprowadzały niemieckie siły zbrojne do

\footnotetext{
1 Konwencja rozejmowa z Niemcami, [w:] S. Sierpowski, Źródła do historii powszechnej okresu międzywojennego, t. I, Poznań 1989, s. 63-66; M. Gilbert, Pierwsza wojna światowa, Poznań 2003, s. 504.

2 P. Grupp, Vom Waffenstillstand zum Versailler Vertrag, [w:] Die Weimarer Republik 1918-1933, Bonn 1988, s. 291-293.

3 Konwencja rozejmowa między Mocarstwami Sprzymierzonymi i Stowarzyszonymi a Niemcami, [w:] Powstanie II Rzeczypospolitej, pod red. H. i J. Jędruszczaków, Warszawa 1984, s. 479.
} 
roli sił porządkowych służących bardziej celom polityki wewnętrznej niż ewentualnej obrony państwa. Ograniczona do 100 tys. zawodowa armia pozbawiona została prawa posiadania czołgów, ciężkiej artylerii, lotnictwa, okrętów podwodnych, flota wojenna została zredukowana do 36 okrętów, rozwiązano Sztab Generalny, zakazano poboru, zdemilitaryzowano cały zachodni brzeg Renu i 50-kilometrowy pas na wschodnim brzegi rzeki ${ }^{4}$.

$\mathrm{Na}$ mocy traktatu wersalskiego Niemcy zostały zmuszone do rozbrojenia i zniszczenia wszystkich urzqdzeń obronnych, twierdz i fortyfikacji lądowych znajdujacych się na terytorium niemieckim na zachód od linii przeprowadzonej o $50 \mathrm{~km}$ na wschód od Renu (art. 180). Także odbudowa lub budowa nowych fortyfikacji w tej strefie były zabronione. Art. 115 wprowadzał identyczne rygory w odniesieniu do fortyfikacji nadmorskich od Półwyspu Jutlandzkiego po Mielno (9-16 $6^{\circ}$ dł. geogr. wsch.). Z kolei w odniesieniu do pozostałej części wybrzeża na głębokości $50 \mathrm{~km}$ oraz wysp przybrzeżnych wprowadzono zakaz wznoszenia nowych budowli, rozbudowy istniejącego uzbrojenia artyleryjskiego oraz ograniczono dopuszczalne zapasy amunicji do 1500 pocisków na każde działo o kalibrze do $105 \mathrm{~mm}$ i 500 pocisków na działa wyższego kalibru (art. 196) ${ }^{5}$.

Końcowy akapit art. 180 odnosił się także do pozostałych fortyfikacji niemieckich: System obronny granic na południu $i$ na wschodzie Niemiec będzie utrzymany $w$ stanie obecnym ${ }^{6}$.

Ogólnikowość tego zapisu pozostawiała już współczesnym dużą dozę swobody interpretacji, a oczywiste prawo do konserwacji istniejących fortyfikacji z łatwością mogło być rozszerzone na modernizacje. W zamyśle autorów owego zapisu służyć on miał za swoiste zabezpieczenie Zachodu na wypadek rozprzestrzenienia się zagrożenia bolszewickiego w przypadku klęski i upadku Polski i jako taki nie był wymierzony w wschodniego sąsiada Niemiec ${ }^{7}$.

Opuszczający Paryż członkowie delegacji wyjeżdżali z przeświadczeniem, że narzucone Niemcom warunki nie stworzyły w Europie fundamentów trwałego pokoju. Podstawowy cel, a więc fizyczne osłabienie Niemiec był sukcesem jedynie pozornym. Zwycięski wódz naczelny marszałek Ferdynand Foch miał racje, mówiąc o Traktacie Wersalskim: To nie pokój, to zawieszenie broni na dwadzieścia lat ${ }^{8}$.

$$
* * *
$$

\footnotetext{
4 Traktat pokojowy z Niemcami, [w:] S. Sierpowski, Źródta do historii..., s. 117-120; J. Krasuski, Historia Niemiec, Wrocław-Warszawa-Kraków 1998, s. 337-338.

5 T. Rawski, Niemieckie umocnienia na ziemiach polskich w latach 1919-1945, Studia i Materiaty do Historii Wojskowości, t. XII, 1966, cz. 1, s. 284-285.

6 Traktat pokojowy..., s. 118.

7 W. Łach, System obronny Prus Wschodnich do 1935 r., Olsztyn 1997, s. 124-125.

8 H. Kissinger, Dyplomacja, Warszawa 1996, s. 268.
} 
Przełom roku 1918 i 1919 to nie tylko okres wielkiego zamętu wewnętrznego w Niemczech wywołanego rewolucją i walką o kształt ustrojowy nowego państwa. Część kręgów politycznych i militarnych pragnęła wykorzystać fakt, iż Niemcy nie były okupowane, a większość społeczeństwa nie chciała pogodzić się z klęską wojenną lub nie miała jej świadomości. Sposób na przeciwstawienie się aliantom i tym samym wywalczenie odpowiedniej pozycji przetargowej w trakcie konferencji pokojowej dostrzegano w aktywnych działaniach na wschodzie. Zwłaszcza niepewna sytuacja w Rosji wydawała się odpowiednią okazją do akcji militarnej na obszarze nadbałtyckim. Źródłem tych zainteresowań republikami nadbałtyckimi były nie tylko tradycyjne wpływy niemieckie na tym obszarze, ale także alternatywne koncepcje ograniczenia negatywnych skutków traktatu pokojowego. Tak zrodziła się koncepcja tzw. Oststaat - niemieckiego państwa wschodniego. Wyodrębnienie i usamodzielnienie się prowincji wschodnich mogło stanowić sposób na wyłączenie części państwa niemieckiego spod konsekwencji przegranej wojny. Większość wariantów tego planu sprowadzała się do oparcia nowego państwa na Prusach Wschodnich i Zachodnich, a także ewentualnych nabytkach nadbałtyckich. Jednym z głównych orędowników tej koncepcji był gen. Rüdiger von der Goltz, dowódca IV Korpusu Rezerwowego stacjonującego na terenie Łotwy. Zasadnicze zaplecze polityczne stanowiła część konserwatywnych, monarchistycznych elit pruskich z rezerwą, a często nieukrywaną pogardą odnoszących się do rzeczywistości republikańskich Niemiec. Nie bez znaczenia było oddalenie owych prowincji od centrum wydarzeń politycznych i znikomy poziom zrewolucjonizowania społeczeństwa. Nie bez znaczenia była także kwestia przebiegu przyszłej granicy z Polską. Wybuchłe 27 grudnia 1918 r. Powstanie Wielkopolskie dowiodło, iż o kształcie tej granicy zadecydują nie tylko debaty dyplomatyczne9.

W połowie lutego 1919 r. z Wilhelmshöhe pod Kassel do Kołobrzegu przeniosło się niemieckie Naczelne Dowództwo (Oberste Heeresleitung - OHL), na którego czele w dalszym ciągu stał marszałek Paul von Hindenburg. Dowództwu podporządkowane zostały dwa nowe dowództwa regionalne: Armeeoberkommando Nord w Królewcu i Armeeoberkommando Süd we Wrocławiu. Zadaniem AOK Nord, które wkrótce przeniosło się do Bartoszyc, było kierowanie operacjami wojskowymi przeciwko Rosji Radzieckiej, a także przygotowanie ewentualnych działań przeciwko Polsce z kierunku północnego. Z kolei zadaniem dowództwa południowego było przygotowanie ewentualnego uderzenia na Polskę z kierunku Wielkopolski i Śląska, a także działania przeciwko Czechosłowacji ${ }^{10}$.

\footnotetext{
9 P. Łossowski, Między wojna a pokojem - niemieckie zamysty wojenne na wschodzie w obliczu traktatu wersalskiego, marzec-czerwiec 1919 r., Warszawa 1976, s. 18-22.

10 B. Jacobs, Nowa armia niemiecka i jej wodzowie, Warszawa 1937, s. 6-9; H. von Seeckt, Aus seinem Leben, Leipzig 1940, s. 133-134.
} 
Kres tym planom położyła odpowiedź aliantów na kontrpropozycje niemieckie do traktatu pokojowego z 16 czerwca 1919 roku. Ratyfikacji Traktatu Wersalskiego przez Sejm Rzeszy w dniu 23 czerwca towarzyszyła narada OHL, w trakcie której rozważano możliwość podjęcia działań militarnych na wschodzie celem niedopuszczenia do odłączenia Prus Zachodnich od Niemiec i odsunięcia groźby utraty części Prus Wschodnich. 25 czerwca do dymisji podał się marszałek Hindenburg, a 3 dni później delegacja niemiecka podpisała w Wersalu upokarzający Niemcy traktat pokojowy. Zapisy pokoju miały wejść w życie 10 stycznia 1920 r., a nad ich przestrzeganiem czuwać miała Międzysojusznicza Wojenna Komisja Kontroli ${ }^{11}$.

Odpowiedzią na niemożność podjęcia oficjalnych działań przeciwko zagrożeniom zewnętrznym (Polacy w Wielkopolsce i na Górnym Śląsku) i wewnętrznym (separatyzm bawarski, nadreński i wschodniopruski) było powstanie, często za zgodą i wsparciem władz, i działania formacji ochotniczych Freikorps. Oficjalnie pozostające poza możliwością oddziaływania rządu i armii, faktycznie dowodzone przez oficerów weteranów, stały się skutecznym narzędziem oddziaływania militarnego wewnątrz Niemiec, na jego pograniczach, a także na obszarze Litwy i Łotwy.

Jak donosiły raporty wywiadu polskiego, równolegle zaczęto rozbudowę licznych organizacji paramilitarnych typu: Schutzbund, Heimwehr, Bürgerwehr, Einwohnerwehr, Jugendwehr, Heimatschutz, Sicherheitspolizei. Organizacje te stały się przechowalnią dla demobilizowanych formacji Reichswehry i Grenzschutzu. Członkowie tych formacji byli uzbrojeni nie tylko w broń ręczną, ale także w artylerię. Twierdza Boyen w Giżycku była jednym z większych magazynów broni i amunicji. $\mathrm{Z}$ chwilą przybycia obserwatorów alianckich magazyny te przeniesione zostały w rejon Pozezdrza, Ogonek i Węgorzewa, a więc poza granice obszaru plebiscytowego. Dodatkowym elementem nacisku psychologicznego, a zarazem narzędziem często brutalnej agitacji stały się bałtyjskie Freikorpsy wycofywane od jesieni 1919 r. z państw bałtyckich do Prus Wschodnich i rozlokowywane w większości na obszarze plebiscytowym ${ }^{12}$.

Cechą polityki dowództwa Reichswehry było nieangażowanie się w wewnętrzne konflikty i budowanie własnej niezależności od państwa. Finałem tej polityki była dwuznaczna postawa armii w okresie puczu Kappa w marcu $1920 \mathrm{r}$. Jej efektem było odwołanie socjaldemokratycznego ministra obrony. Nowym ministrem, piastującym ten urząd aż do stycznia 1928 roku, został Otton Gessler, zaś dowództwo nad Reichswehrą objął gen. Hans von Seeckt. Tym samym zapoczątkowana została tzw. „era Seeckta”. W okresie tym (do 1926 r.) konstytucyjna

11 H. von Seeckt, Aus seinem..., passim.

12 Plebiscyt na Warmii, Mazurach i Powiślu w 1920 r. Wybór źródeł pod red. P. Staweckiego i W. Wrzesińskiego, Olsztyn 1986, s. 78-79, 230-231, 236; W. Wrzesiński, Plebiscyt na Warmii, Mazurach i Powiślu w 1920 r., Olsztyn 1974, s. 135. 
zwierzchność ministra obrony nad armią stała się fikcją. Gen. von Seeckt uzyskał pełnię władzy nad siłami zbrojnymi, a minister Gessler skoncentrował się na ukrywaniu przed Międzysojuszniczą Komisją Kontroli, a także własnym parlamentem, nielegalnej działalności Reichswery ${ }^{13}$.

Znowelizowana 23 marca 1921 roku ustawa o siłach zbrojnych ostatecznie ukształtowała obraz Reichswehry.

Zgodnie z nią skład Reichswehry określono na 96 tys. żołnierzy i 4 tys. oficerów. Armia składała się z 7 dywizji piechoty i 3 dywizji kawalerii, a kraj podzielono na 7 okręgów wojskowych ${ }^{14}$.

Okręg I z dowództwem w Królewcu obejmował Prusy Wschodnie. Na terenie Prus Wschodnich rozmieszczona została 1 Dywizja Piechoty gen. von Dassel'a. Dowódca dywizji był jednocześnie dowódcą okręgu, któremu poza związkami dywizyjnymi podlegały ponadto oddziały podporządkowane dowództwu okręgu, obozy warowne, place ćwiczeń i urzędy wojskowe. Dowództwo okręgu, będące jednocześnie dowództwem dywizji, składało się z szefa sztabu wraz ze sztabem, adiutanta oraz oficerów rodzajów broni i służb. W skład dywizji piechoty wchodziło dowództwo piechoty, dowództwo artylerii, trzy pułki piechoty, pułk artylerii, trzy kompanie moździerzy, batalion saperów, batalion łączności, oddział sanitarny, dwa oddziały transportowe i wydzielone z dywizji kawalerii szwadrony jazdy. Każdy pułk piechoty składał się z trzech batalionów piechoty, batalionu szkolnego i kompanii moździerzy, natomiast bataliony tworzyły trzy kompanie piechoty i kompania ciężkich karabinów maszynowych ${ }^{15}$.

Macierzystymi garnizonami I Okręgu Wojskowego były ${ }^{16}$ :

- Królewiec - dowództwo dywizji, dowództwa: 1 pułku piechoty, pułku artylerii, 1 batalionu saperów, I oddziału łączności, I oddziału taborów, I oddziału transportowego, I oddziału sanitarnego, 1 batalion piechoty, batalion szkolny 1 pułku, 2 dywizjon artylerii, kompania moździerzy i dywizjon szkolny;

- Olsztyn - dowództwo 2 pułku piechoty, batalion szkolny 2 pułku, 1, 3 i 5 szwadron 2 pułku kawalerii, 3 dywizjon artylerii, kompania moździerzy;

- Iława - dowództwo 3 pułku piechoty, 2 batalion 3 pułku, kompania moździerzy;

- Tylża — dowództwo 1 pułku kawalerii wraz z 1, 4 i 5 szwadronem pułku;

13 H. A. Jacobsen, Militär, Staat und Geselschaft in der Weimarer Republik, [w:] Die Weimarer Republik, s. 349-350; J. Krasuski, Historia..., s. 367-368; H. Möller, Weimar - niespetniona demokracja, Warszawa 1997, s. 169-170.

14 A. Szymański, pseudonim „Mars”, Sity zbrojne Niemiec, Warszawa 1931, s. 18-19; J. Benoist-Mechin, Niemcy i armia niemiecka 1918-1935, cz. 1, Warszawa 1939, s. 58-61.

15 A. Szymański, pseudonim „Mars”, Sity zbrojne..., s. 26-37.

16 Ibidem. 
- Wystruć - 2 batalion 1 pułku piechoty, 2 i 3 szwadron 1 pułku kawalerii, 1 dywizjon artylerii;

- Gąbin - 3 batalion 1 pułku piechoty;

- Ostróda - 3 batalion 3 pułku piechoty, dowództwo 2 pułku kawalerii wraz z 2, 4 i 6 szwadronem;

- Szczytno - 1 batalion 2 pułku piechoty;

- Kętrzyn - 2 batalion 2 pułku piechoty;

- Giżycko - 3 bat. 2 pułku piechoty;

- Malbork - 1 batalion i batalion szkolny 3 pułku piechoty.

Ograniczenia militarne Traktatu Wersalskiego w znaczący sposób wpływały na planowanie wojenne Reichswehry. Gen. von Seeckt dążył do stworzenia doskonałej armii zawodowej, która stać się miała bazą dla powołania nowych sił zbrojnych. Stąd też w procesie szkolenia zwracano uwagę na przygotowanie podoficerów i oficerów młodszych do piastowania wyższych stanowisk dowódczych. Brak możliwości szkolenia rezerw spowodowany narzuconym przez aliantów 12-letnim okresem służby zawodowej starano się „omijać” za sprawą tzw. „ochotników okresowych" (Zeitfreiwillige). Wykorzystując zaburzenia roku 1923, utworzono formacje tzw. „,czarnej Reichswehry” zakamuflowane jako „oddziały robocze” (Arbeitskommando). Jednak podstawowym źródłem przeszkolonych rezerw były liczne organizacje kombatanckie i paramilitarne. To właśnie za ich sprawą starano się utrzymać pewną rezerwę przeszkolonych weteranów wojennych, a także przygotowywano kolejne roczniki młodzieży. Organizacje te częstokroć wykorzystywały w szkoleniu nielegalnie przechowywaną broń. Szczególną rolę w kalkulacjach dowództwa Reichswehry zajmował Stahlhelm - prawicowa organizacja kombatancka skupiająca w swoich szeregach zasadniczą część cesarskiego korpusu oficerskiego ${ }^{17}$.

Wbrew postanowieniom traktatowym gen. von Seeckt utrzymał dawny sztab generalny pod nową nazwą Urzędu Wojskowego (Truppenamt) działającego jako departament Ministerstwa Obrony. Skupiał on najzdolniejszych oficerów młodszego pokolenia posiadających doświadczenie wojenne, natomiast podstawowym zadaniem Truppenamtu było opracowywanie przyszłościowych planów mobilizacyjnych, planów rozbudowy sił zbrojnych, planów wojennych oraz nowatorskich koncepcji prowadzenia wojny ${ }^{18}$.

Słabość militarna Republiki Weimarskiej wykluczała możliwość podjęcia jakichkolwiek działań wymierzonych przeciwko Polsce. Stąd też dowództwo Reichswehry nie ukrywało nadziei na klęskę Polski w wojnie polsko-bolszewickiej. W opinii gen. von Seeckta: Obecne państwo polskie jest dziełem Ententy. Ma

\footnotetext{
17 J. Krasuski, Historia..., s. 368.

18 Tamże; P. Masson, Historia Wehrmachtu 1939-1945, Warszawa 1995, s. 10-11; W. Kozaczuk, Wehrmacht 1933-1939, Warszawa 1971, s. 9-11.
} 
ono zastapić Rosję w wywieraniu nacisków na Niemcy na froncie wschodnim. Wojna Rosji Sowieckiej z Polskq uderzyła nie tylko w ten drugi kraj, ale przede wszystkim w Ententę - we Francję $i$ Wielka Brytanię. Jeśli Polska się zawali, runięcie grozi catemu gmachowi Traktatu Wersalskiego. Z powyższego jasno wynika, że Niemcy nie sq zainteresowane $w$ udzieleniu pomocy Polsce $w$ jej walce $z$ Rosja ${ }^{19}$.

Stąd też było jedynie kwestią czasu, kiedy oba kraje złączone wspólną wrogością wobec Polski zawrą formalny sojusz. Zawarty 16 kwietnia 1922 r. w Rapallo układ radziecko-niemiecki doprecyzowany został w przeciągu roku tajnymi porozumieniami wojskowymi i gospodarczymi ${ }^{20}$.

Pierwszy niemiecki plan wojny z Polską opracowany został pod kierownictwem gen. von Seeckta w latach 1923-1926. Już w lutym 1924 r. w ramach Oddziały T2 Truppenamtu powołana została tajna grupa składająca się z 14 młodych oficerów. Pod „,przykrywką" zespołu dyskusyjnego pracującego nad koncepcjami nowoczesnej wojny w rzeczywistości opracowywali oni założenia tzw. „Wielkiego Planu” (Der Grosse Plan). Cele grupy określone zostały przez gen. von Seeckta w 1923 r. - przygotowanie założeń teoretycznych do odbudowy sił zbrojnych w wymiarze 2,8 do 3 milionów żołnierzy, podzielonych na 63 dywizje polowe i 39 „stacjonarnych” dywizji Grenzschutzu. Razem 102 dywizje, a więc potencjał odpowiadający armii z 1914 roku. Prace zakończono na początku 1925 r., po czym zapoczątkowano kilkuletnie analizy uwarunkowań ekonomiczno-finansowych. Same analizy możliwości mobilizacyjnych wskazywały jednoznacznie, iż już od $1931 \mathrm{r}$. podstawowym problemem armii będzie zapewnienie odpowiednio licznych roczników mężczyzn mających za sobą służbę wojskową. To też skłoniło zespół planistów do przygotowania zastępczego planu pod kryptonimem Das 21-Divisionen-Heer - armia 21 dywizyjna. Od maja 1925 r. projekt ten znany był części oficerom Truppenamtu pod kryptonimem „Alexander”. Cel dla tej armii określił precyzyjnie sam gen. von Seeckt: musimy zdobyć site, a gdy tylko tę site posiadziemy odzyskamy naturalnie wszystko to, co straciliśmy ${ }^{21}$.

Plan wojny z Polską zakładał:

- uderzenie głównymi siłami z pozycji wyjściowej Piła-Wałcz w kierunku na Poznań, Płock i Łowicz celem zmuszenia sił polskich do opuszczenia „Korytarza” i rezygnacji z ewentualnego ataku na Prusy Wschodnie;

- wykonanie pomocniczego uderzenia z rejonu Kwidzyń-Susz-Iława w kierunku na Grudziądz i Toruń celem wyjścia na tyły wojsk polskich wycofujących się z Pomorza;

19 H. Kissinger, Dyplomacja, s. 280.

20 Ibidem, s. 283; S. Haffner, Diabelski pakt. Z dziejów stosunków niemiecko-rosyjskich 19171941, Lublin 1994, s. 84-87.

21 C. Dirks, K-H. Janßen, Der Krieg der Generäle, München 2001, s. 11-27. 
- po zakończeniu mobilizacji prowadzenie dalszych działań zaczepnych z rejonu Kluczbork-Olesno na Piotrków i Łódź;

- obronę Górnego Śląska siłami obrony terytorialnej22.

$\mathrm{Z}$ uwagi na wymienione uwarunkowania powstały w latach 20 . zakonspirowane organizacje Landesschutz skupiające starych, wypróbowanych żołnierzy posiadających doświadczenie wojenne. Ewentualne wykorzystanie tych ludzi było jednak wysoce wątpliwe. Utrzymywano jednak pewną gotowość, prowadzono także listy zdolnych do służby wojskowej, organizowano tajne szkolenia ${ }^{23}$.

Plan ten do początku lat 30 . systematycznie aktualizowany pozbawiony był jednak podstaw materialnych i stanowił wyłącznie materiał teoretyczny. Polska jako główny przeciwnik Niemiec była silniejsza militarnie, a dodatkowo należało brać pod uwagę sojusz polsko-francuski. W efekcie cel, jakim było zniszczenie państwa polskiego, pozostawał w sferze teorii. Obawiając się z kolei uderzenia polskiego na Prusy Wschodnie, Niemcy wyznaczyli Pomorzu rolę kluczowego teatru działań wojennych. Wykorzystując barierę Wisły uniemożliwiającej rozwinięcie poważniejszych sił polskich, zdecydowano się na wykonanie koncentrycznego uderzenia z Pomorza Zachodniego i zachodniego pogranicza Prus Wschodnich. Zasadniczym celem było nie tyle rozbicie sił polskich skoncentrowanych na Pomorzu, co przede wszystkim niedopuszczenie do ataku na Prusy Wschodnie. Obawa o los tej prowincji była zasadniczym ogniwem, wokół którego koncentrowały się plany wojenne Republiki Weimarskiej.

8 października 1926 r. gen. von Seeckt odwołany został ze stanowiska. Jego następca gen. Wilhelm Heye kontynuował dzieło odbudowy armii. Nie zaszkodziła temu afera związana z ujawnieniem w grudniu 1926 r. na forum parlamentarnym kulis tajnej współpracy Reichswehry z Armią Czerwoną, a także dyskusyjnych, co do legalności modernizacji fortyfikacji na granicy wschodniej. Okolicznością łagodzącą okazało się natomiast zaprzestanie działalności Międzysojuszniczej Komisji Kontroli w lutym 1927 roku. Wówczas też gen. Heye mógł „ujawnić” tajne zasoby Reichwehry. W ukrytych magazynach armii i organizacji z nią współdziałających znajdowało się 350 tys. karabinów, 12 tys. karabinów maszynowych, 400 moździerzy i 675 dział. Potencjał ten z pewnością wystarczył dla wystawienia projektowanych w przeszłości 39 dywizji Grenzschutzu!24

W styczniu 1928 r. nowym ministrem obrony zostaje gen. Wilhelm Groener. Wraz z jego pojawieniem się uruchomiono pierwszy 5-letni plan zbrojeniowy. Zintensyfikowaniu uległy stosunki z Armią Czerwoną, a kolejne grupy oficerów niemieckich szkoliły się w tajnych bazach w Lipiecku, Kazaniu i „Tomka” koło Saratowa. W przedstawionym w 1930 r. zadaniach dla armii gen. Groener

\footnotetext{
22 B. Jacobs, Nowa armia..., s. 55-56; W. Kozaczuk, Wehrmacht.., s. 226.

23 K. Dieckert, H. Grossmann, Der Kampf um Ostpreussen, München 1965, s. 16.

24 C. Dirks, K-H. Janßen, Der Krieg..., s. 35-37.
} 
kładł nacisk na poprawę wyników szkolenia, skrócenie czasu osiągania zdolności wymarszowej przez jednostki, dozbrojenie w nowocześniejsze i cięższe rodzaje uzbrojenia, a ostatecznie - opracowanie planów powiększenia Reichwehry do 21-24 dywizji, których mobilizację osłaniać miało 39 dywizji Grenzschutzu. Scenariusz ten opracowano na potrzeby tzw. „planu Piłsudski” zakładającego możliwość ataku ze strony Polski. Jego urzeczywistnienie możliwe było dopiero od 1938 r., po zakończeniu drugiego 5-letniego planu zbrojeniowego na lata 1933-1938, a uzależniane konsekwentnie od korzystnej sytuacji politycznej na arenie międzynarodowej i zainicjowanej przez Polskę agresji. Było to zgodne z strategią Gustava Stresemanna: wojna z Polska nigdy nie będzie zaczęta przez Niemcy ${ }^{25}$.

W 1930 r. gen. Heye'ego na stanowisku dowódcy Reichswehry zastąpił gen. Kurt Freiherr von Hamerstein-Equord. Wówczas też skonkretyzowano plany 21 dywizyjnej armii. Opracowany przez Truppenamt „Plan A” (A-Plan) zakładał rozwinięcie w pierwszej fali mobilizacji 7 istniejących dywizji do 21 (każdy istniejący pułk stawał się zalążkiem nowej dywizji), po czym w drugiej fali kolejnych 14 dywizji, a w trzeciej - 7 dywizji. Łącznie 42 dywizje piechoty plus 8 dywizji kawalerii o łącznej sile 550 tys. żołnierzy. Do tego dochodziły planowane wcześniej dywizje Grenzschutzu i inne jednostki towarzyszące, co łącznie oznaczało zmobilizowanie ok. 1,3 miliona mężczyzn i ponad 360 tys. koni. Wysiłek ten wymagał zabezpieczenia 14 miliardów marek ${ }^{26}$.

Problem niedostatku odpowiedniej ilości przeszkolonych rezerw starano się minimalizować tajnymi działaniami. Doskonałym przykładem były kroki podjęte przez gen. Blomberga, który w okresie 1929-1933 dowodził wschodniopruskim I Okręgiem Wojskowym. Na kilkutygodniowych kursach szkolono tzw. Zeitfreiwillige, a także tych, którzy nie posiadali przeszkolenia wojskowego. Podstawowym celem było z jednej strony pielęgnowanie i odświeżanie podstawowych umiejętności wśród byłych żołnierzy, a dodatkowo szkolenie nowych kadr. Na specjalnych kursach uczono obsługi karabinów maszynowych, moździerzy, a także dział polowych. W tym ostatnim wypadku jedynie dowódca działa był byłym żołnierzem, pozostali to prości synowie chłopscy, ale i nie tylko. M.in. ochotnicy z Wolnego Miasta Gdańska przechodzili przeszkolenie w Prusach Wschodnich. Zgodnie z koncepcją płk. von Stülpnagela siły te miały być wykorzystywane do tzw. „małej wojny”, a więc działań prowadzonych na głębokich tyłach, już po inwazji przeciwnika ${ }^{27}$.

Chcąc uwiarygodnić potrzebę powołania silnej armii, 10 stycznia $1933 \mathrm{r}$. szef Truppenamtu gen. Adam zlecił swoim oficerom przygotowanie gry wojen-

\footnotetext{
25 Ibidem, s. 40-41.

26 Ibidem, s. 42-43.

27 C. Dirks, K-H. Janssen, Der Krieg..., s. 39.
} 
nej obrazującej fikcyjny atak ze strony Polski. Do obrony Niemiec Reichwehra wystawiła 27 dywizji polowych, 34 słabe dywizje Grenzschutzu i 3 dywizje kawalerii. Atak przypuściło 40 do 46 polskich dużych związków taktycznych. W następstwie tego ataku Prusy Wschodnie zostały utracone, a dwie polskie armie stanęły nad Odrą, $100 \mathrm{~km}$ od Berlina. Dopiero po 3 tygodniach siły niemieckie przeszły do kontruderzenia. Szok wywołany przebiegiem gry służyć miał uzasadnieniu konieczności poniesienia zwiększonych wydatków na armię. Taki w treści memoriał przedstawił gen. Adam wiosną 1933 r. nowemu ministrowi obrony gen. Wernerowi von Blomberg. Wskazywał w nim ponadto na nikłą wartość formacji Grenzschutzu, a także słabość Reichswehry w zaopatrzeniu w amunicję (14 dniowy zapas). Informacje te skutecznie zniechęcały do jakiejkolwiek reakcji na wprowadzenie garnizonu polskiego na Westerplatte ${ }^{28}$.

Gen. Blomberg mógł zapoznać z treścią tego dokumentu nowego kanclerza Niemiec, Adolfa Hitlera.

$$
* * *
$$

Równolegle z działaniami o charakterze ogólnowojskowym, kontynuowano działania służące wzmocnieniu infrastruktury obronnej Prus Wschodnich, w tym zwłaszcza obszarów ufortyfikowanych.

Doświadczenia I wojny światowej skłaniały licznych dowódców do podjęcia dyskusji nad sensem i kierunkami rozwoju nowoczesnej fortyfikacji. Intensywny rozwój artylerii skłaniał do postawienia tezy, iż każda konstrukcja będzie mogła być zniszczona jej ogniem. Czy warto w związku z tym marnotrawić znaczne środki finansowe na budowanie umocnień $\mathrm{z}$ góry skazanych na porażkę $\mathrm{w}$ pojedynku z artylerią? W wymiarze taktycznym fortyfikacje stawały się swoistymi klatkami dającymi pewne schronienie, ale wykluczającymi za razem możliwość wykonania manewru zgromadzonymi tam siłami. Kryzys gospodarczy okresu powojennego stawiał także pod znakiem zapytania możliwość wyasygnowania tradycyjnie już wysokich kwot na budowę fortyfikacji ${ }^{29}$.

Szczególnie w odniesieniu do dużych twierdz pierścieniowych pojawiły się poważne wątpliwości, co do możliwości i sensu ich utrzymywania. Doświadczenia wojny światowej wskazywały, iż poza Verdun praktycznie wszystkie tego typu twierdze padły. Donośność ówczesnej artylerii sprawiała, iż chcąc zabezpieczyć rdzeń twierdzy przed ogniem przeciwnika, musiałaby ona mieć promień minimum $25 \mathrm{~km}$, co przekładało się na obwód o długości ok. $150 \mathrm{~km}$. Zabezpieczenie takiego obwodu wymagałoby ok. 10 dywizji. W wypadku Niemiec doby lat 20. czysta abstrakcja. Inaczej jednak wyglądała sytuacja mniejszych,

28 Ibidem, s. 44-45.

29 C. Benoit, Fortyfikacja stała podczas wojny, Warszawa 1924, s. 58-59; M. Berezowski, Rozwój obrony pozycyjnej w I wojnie światowej, Myśl Wojskowa, 1951, t. 2, s. 181-184. 
tym samym mniej kosztownych twierdz zaporowych położonych $\mathrm{z}$ reguły na skrzyżowaniu ważnych szlaków komunikacyjnych, często w miejscach trudno dostępnych ${ }^{30}$.

Alternatywą dla fortyfikacyjnych obiektów odosobnionych stawały się obiekty półstałe - fortyfikacja odcinkowa. Pogląd ten znalazł szczególnie wielu zwolenników w Niemczech. Koronnym przykładem i dowodem skuteczności fortyfikacji odcinkowych były dla jej zwolenników Prusy Wschodnie i kampania 1914/1915 r. Podstawową zaletą tej formy fortyfikacji było zachowanie zdolności manewrowych osłanianych przez nie wojsk. W przypadku ataku przeciwnika zapewniały one możliwość przeprowadzenia koncentracji wojsk i manewru po liniach wewnętrznych, po czym wyprowadzenia uderzenia na skrzydło przeciwnika. Ten scenariusz był źródłem sukcesu Hindenburga. Wadą fortyfikacji odcinkowej była jednak możliwość jej oskrzydlenia, ominięcia. Stąd też w rozważaniach koncentrowano się na kwestii wydłużenia owych odcinków. Biorąc ponownie pod uwagę możliwości ówczesnej artylerii, stwierdzono, iż minimalna długość odcinka powinna równać się podwójnej donośności artylerii ${ }^{31}$.

W końcówce lat 20. fortyfikacje odcinkowe stały się podstawą tworzenia tzw. rejonów umocnionych (RU), na których oparto system obronny Francji i Niemiec.

W wypadku Niemiec, poza doświadczeniami wojennymi, istotne znaczenie dla sukcesu koncepcji rejonów umocnionych miały uwarunkowania traktatowe i ekonomiczne. Według założeń niemieckich RU miały spełniać trzy podstawowe warunki:

- niemożliwe do przełamania;

- trudne do obejścia lub okrążenia;

- odporne na możliwość jego przeniknięcia.

Niemożność przełamania zapewnić miał system środków ogniowych zaopatrzony w stałe obiekty fortyfikacyjne, dostosowane do terenu i zamaskowane. Rozmieszczenie dzieł fortyfikacyjnych powinno zapewnić silną zaporę ogniową wzdłuż całego frontu. Kilkustrefowy ogień broni maszynowej i artylerii miał być flankujący. Bezpośredni styk sąsiadujących ze sobą RU lub oparcie ich skrzydeł na istniejących naturalnych przeszkodach terenowych bądź sztucznie stworzonych strefach zniszczenia utrudnić miało obejście RU. Uodpornienie RU na przenikanie zamierzano osiągnąć poprzez tzw. uelastycznienie obrony, tzn. wciągnięcie przeciwnika w głąb własnego systemu obrony i zniszczenie go ogniem i manewrem ${ }^{32}$.

30 K. Kleczke, W. Wyszyński, Fortyfikacja stała, Warszawa 1937, s. 145; T. Zieleniewski, Wspótczesna myśl w fortyfikacji statej, Bellona, 1928, t. XXII, s. 174.

31 J. Niesiołowski, Zagadnienie fortyfikacji stałej, Bellona, 1927, t. XXVI, z. 4, passim.

32 W. Lach, System obronny..., s. 130-131. 
Rejony umocnione planowano tworzyć przede wszystkim dla obrony granic, zapewnienia przeprowadzenia mobilizacji, koncentracji i rozwinięcia sił własnych, a także dla osłony szczególnie ważnych ośrodków, cieśnin i ważniejszych kierunków. $\mathrm{Z}$ założenia stanowić one miały ponadto podstawę wyjściową dla ewentualnego własnego uderzenia. Sam fakt istnienia RU powinien ponadto wpłynąć na poczynania przeciwnika poprzez zmuszenie go do planowania obejścia lub przeznaczenia znacznych sił dla ich przełamania ${ }^{33}$.

Ten ostatni aspekt miał istotne znaczenie $\mathrm{z}$ punktu widzenia dowództwa Reichswehry. Rejony umocnione umożliwiały racjonalne wykorzystanie ograniczonych i tak do minimum sił.

Poza negatywnymi konsekwencjami izolacji ekonomicznej, również w warstwie militarnej Prusy Wschodnie znajdowały się w bardzo nieszczęśliwej sytuacji. Z siedmiu dywizji tylko jedna stacjonowała w Prusach Wschodnich. Prowincja była w prawdzie militarnie lepiej wyposażona niż pozostałe części Rzeszy, ale o skutecznej obronie granicy nie mogło być mowy. Zwłaszcza w kontekście stałego napięcia z Polską, która według wszystkich danych musiała uchodzić za głównego przeciwnika. Jako twierdze zachowane zostały Królewiec, Giżycko i Piława ${ }^{34}$.

Zapisy Traktatu Wersalskiego pozostawiały możliwość modernizacji części fortyfikacji wschodniopruskich. Swobodę takową pozostawiały mało precyzyjne zapisy art. 180 traktatu.

Już w 1920 r. odpowiadająca za zachowanie i rozbudowę fortyfikacji niemieckich Inspekcja Saperów i Fortyfikacji rozpoczęła prace planistyczne, które koncentrowały się na zabezpieczeniu granicy wschodniej, a zwłaszcza Prus Wschodnich. Poza istniejącymi fortyfikacjami (Wrocław, Głogów, Kostrzyń, Piława, Królewiec, Giżycko) obronę tej granicy zamierzano oprzeć na wszelkiego typu przeszkodach naturalnych, takich jak rzeki, jeziora, bagna i lasy. Jednocześnie opracowywano plany uzupełnienia ich w wypadku zagrożenia rejonami umocnionymi.

Nie mogąc podjąc nowych inwestycji fortyfikacyjnych, fortyfikatorzy niemieccy siłą rzeczy skoncentrować się musieli na modernizacji istniejących linii obronnych. W wypadku Prus Wschodnich obiektem owych zainteresowań była twierdza królewiecka, fortyfikacje linii jezior mazurskich z ich głównym ośrodkiem - Fest Boyen w Giżycku, a także szczycieńska pozycja leśna.

Twierdza Królewiecka stanowiła w dalszym ciągu zasadnicze ogniwo obrony wschodniego pogranicza prowincji. Traktat Wersalski zezwalał na zachowanie w twierdzy części jej uzbrojenia artyleryjskiego, a mianowicie ${ }^{35}$ :

\footnotetext{
33 Ibidem.

34 K. Dieckert, H. Grossmann, Der Kampf..., s. 16.

35 A. Szymański, pseudonim „Mars”, Sity zbrojne..., s. 33.
} 
- 6 armat K.17 kal. $100 \mathrm{~mm}$;

- 12 haubic S.F.H.13 kal. mm;

- 2 armaty K.16 kal. $150 \mathrm{~mm}$;

- 2 moździerze kal. $210 \mathrm{~mm}$;

- 12 dział p.lot. kal. $88 \mathrm{~mm}$;

- 4 działa 4 p.lot. kal. 105 mm.

Była to jedyna ciężka artyleria na obszarze I Okręgu Wojskowego.

Do 1927 r. prace inżynieryjne koncentrowały się na wzmacnianiu i rozbudowie twierdzy. W odległości $10 \mathrm{~km}$ od linii starych fortów wybudowano pas fortyfikacji o długości $20 \mathrm{~km}$ i głębokości $5 \mathrm{~km}$. Łącznie wzniesiono 54 obiekty betonowe.

Odziedziczone po cesarskich Niemczech fortyfikacje „Mazurskiej Pozycji Jeziornej”, rozbudowane w 1914 r. o Giżycką Pozycję Polową, stanowiły doskonałą bazę dla systemu obrony wschodniej granicy Prus Wschodnich.

Zgodnie z inwentaryzacją przeprowadzoną w 1920 r. przez MKK na obszarze tzw. wyspy giżyckiej zlokalizowanych było (poza twierdzą Boyen): 4 - peryskopowe stanowiska obserwacyjne, 4 schrony piechoty, 3 schrony amunicyjne oraz 4 schrony artylerzystów ${ }^{36}$.

W 1927 r. na tym samym terenie znajdowały się (poza wymienionymi wyżej schronami peryskopowymi, piechoty i artylerzystów) także schron łączności, 2 schrony drużynowe piechoty i 2 ukrycia rzutni granatów ręcznych. Wynikało z tego, iż trzy „,nowe” schrony powstały w efekcie ,przebranżowienia” starych schronów amunicyjnych ${ }^{37}$.

W przypadku „Giżyckiej Pozycji Polowej”, obok istniejących w 1920 r. 96 schronów piechoty, 47 schronów pogotowia, 41 wartowni, 11 schronów obserwatorów artylerii, 60 schronów łączności i 9 szop dla sprzętu, pojawiło się 9 nowych drużynowych schronów piechoty.

Nowe obiekty były to standardowe grubościenne schrony żelbetowe, 1i 2-komorowe z przedsionkami lub bez, a także mniejsze, 1-komorowe schrony betonowe na blasze falistej. Wszystkie odpowiadały standardom określonym przez instrukcje fortyfikacyjną z $1925 \mathrm{r}^{38}$

Działania te de facto były pogwałceniem art. 180 Traktatu Wersalskiego, który nawet w odniesieniu do wschodniej granicy Niemiec nie zezwalał na budowę nowych fortyfikacji. Do takich też wniosków doszła w końcowym etapie swojej działalności Międzysojusznicza Komisja Kontroli. Fakt przyjęcia Niemiec 8 września 1926 r. do Ligii Narodów pozwolił na polubowne rozstrzygnięcie za-

\footnotetext{
36 Fortyfikacje XIX I XX-wieczne na obszarze województwa suwalskiego, cz. II, Gdańsk-Giżycko-Suwałki 1998, s. 9.

37 Ibidem.

38 Ibidem.
} 
istniałej sytuacji. Podczas konferencji paryskiej w styczniu 1927 r. Rada Ambasadorów, która przejęła wówczas rolę „kontrolera Niemiec” po wycofaniu MKK, wypracowała kompromisowe rozwiązanie:

- wytyczono pas przygraniczny na wschodzie o głębokości ok. $50 \mathrm{~km}$, w obrębie którego zezwolono na utrzymanie tylko tych fortyfikacji, które istniały w 1919 r. i zostały zinwentaryzowane przez MKK w 1920 r.;

- w wymienionym obszarze zezwolono na zastępowanie materiałów ulegających naturalnemu zniszczeniu (ziemia, cegła, drewno) innym, trwałym budulcem (stal, beton). Nie wolno jednak było budować nowych obiektów fortyfikacyjnych;

- w drodze kompromisu zezwolono na zachowanie w rejonie Giżycka 15, a w okolicy Królewca 31 obiektów, które nie zostały zinwentaryzowane przez MKK w 1920 r. Pozostałe miały być rozebrane do 15 czerwca $1927 \mathrm{roku}$;

- Niemcy złożyły zapewnienie, iż na omawianym obszarze przygranicznym nie istnieją żadne inne obiekty fortyfikacyjne poza ujawnionymi przez $\mathrm{MKK}^{39}$. Wspomniany pas nadgraniczny nie obejmował fortyfikacji rejonu Giżycka, co stwarzało możliwość kontynuowania na tym obszarze dalszych prac fortyfikacyjnych. W odniesieniu do Królewca i szczycieńskiej pozycji leśnej umożliwiono prowadzenie prac konserwacyjnych. Dodatkowym czynnikiem sprzyjającym było „mniejsze zainteresowanie” Rady Ambasadorów kontrolowaniem zbrojeń nowego członka stałego Rady Ligii Narodów.

O ile do 1927 roku teren szczycieńskiej pozycji leśnej był objęty zakazem budowy nowych umocnień, a także monitorowany przez aliancką komisję kontroli (MKK) w związku z wykryciem nielegalnych budów w rejonie Giżycka i Królewca, o tyle po 1927 r. sytuacja uległa zasadniczej zmianie. Nie bez pomocy samych Niemców „rozsypały” się ceglane i drewniane blokhauzy, a stare schrony dzieł piechoty wysadzono w powietrze. W ich miejsce wybudowano latem 1927 roku 45 schronów biernych (ukryć) dla 1-2 drużyn piechoty o grubości ścian $1 \mathrm{~m}$ i stropu 0,8 m (tzw. „Gruppenunterstand”, „Doppelgruppenunterstand") ${ }^{40}$.

Na obszarze punktu oporu (dalej: PO) Ruciane-Nida zburzono cienkie sklepienia pięciu punktów oporu i stanowisk dział w przewoźnych wieżyczkach, zastępując je nowymi żelbetowymi schronami dla drużyny piechoty usytuowanymi już poza obrębem starych obwałowań ziemnych. Także istniejącą przy

39 J. Wiatr, Sprawa rozbrojenia wschodnich fortyfikacji niemieckich, Bellona, 1927, t. XXV, z. 1, s. 102-103; tenże, Rozbudowa twierdz w Królewcu, Kostrzynie i Głogowie, rewelacyjne odkrycie w parlamencie niemieckim, Bellona, 1927, z. 3, s. 291; tenże, Kompromisowe załatwienie sprawy fortyfikacji niemieckich w Królewcu, Kostrzynie i Głogowie, Bellona, 1927, t. XXV, z. 2, s. 213-215.

40 Szczycieńska Pozycja Leśna, [w:] http:/www.ostpreussen.prv.pl 
moście kolejowym wieżę ceglaną zastąpiono żelbetowym schronem dla dwóch drużyn ${ }^{41}$.

Przekonstruowaniu uległ także PO Mikołajki. Zasadnicza zmiana dotyczyła odwrócenia skierowanego dotychczas na wschód frontu, na zachód. W tym celu, po obu stronach mostu drogowego, wzniesiono 3, maskowane jako budynki, schrony bojowe, w tym dwa dla broni maszynowej. W niezmienionym stanie zachowano wieże przy moście kolejowym, zniwelowano natomiast baterie Karłowo o Olszowy Róg ${ }^{42}$.

Również prawdopodobnie w 1928 r. podjęto prace w rejonie Kruklanek. Na wzgórzach położonych na północny-wschód od mostu kolejowego wzniesiono kilka żelbetowych schronów w dwóch odmianach: większe, z pojedynczą strzelnicą i szerokim wjazdem dla działa, oraz mniejsze, z szeroką strzelnicą, tylko częściowo przykryte stropem ${ }^{43}$.

W 1928 roku, w ramach modernizacji mostu na Kanale Niegocińskim (Młyńskim) k. Giżycka rozebrano ceglaną reditę, budując w jej miejscu żelbetowy schron bierny dla 2 drużyn piechoty.

Na odcinku 25-kilometrowej „Piskiej Pozycji Leśnej” (Johannisburger Waldstellung) nie podejmowano żadnych prac modernizacyjnych, ograniczając się jedynie do konserwacji istniejących już obiektów „,pierwszowojennych”.

Jedynym fragmentem Prus Wschodnich, wolnym od ograniczeń w zakresie budowy fortyfikacji, był obszar zamykający się w trójkącie Mrągowo-Morąg-Iława Pruska (ob. Bagrationowsk). Od centralnie położonego w nim Lidzbarka Warmińskiego przyjął on nazwę „Trójkąta Lidzbarskiego” bądź Pozycji Lidzbarskiej (Heilsberg-Stellung).

Prace budowlane zapoczątkowano w 1928 roku. Według oficjalnej propagandy „Trójkąt Lidzbarski” służyć miał zabezpieczeniu Królewca na wypadek niespodziewanego ataku polskiego. W rzeczywistości fortyfikatorzy niemieccy postanowili stworzyć nie tylko nowoczesną rubież obrony w newralgicznym punkcie Prus Wschodnich, ale przede wszystkim zaoferować siłom niemieckim ufortyfikowany rejon koncentracji i mobilizacji zasadniczych sił przeznaczonych do obrony prowincji. Fortyfikacje nadgraniczne wsparte głównie oddziałami Grenzschutzu miały skutecznie opóźniać postępy sił polskich, zaś oddalenie „Trójkąta Lidzbarskiego” dawało dodatkowy niezbędny czas na dokończenie mobilizacji oraz identyfikacji głównych kierunków uderzenia. Można w efekcie zaryzykować tezę, że zadaniem „Trójkąta Lidzbarskiego” było rozszerzenie zakresu oddziaływania Królewca na obronę wnętrza Prus Wschodnich. Tym samym ograniczano swobodę manewru agresora w sytuacji, gdyby sforsował fortyfika-

\footnotetext{
${ }^{41}$ Fortyfikacje XIX $i$ XX-wieczne..., s. 11.

42 Ibidem.

43 Ibidem, s. 12.
} 
cje graniczne. Mankamentem całej koncepcji był 50-kilometrowy pas pomiędzy planowanym „trójkątem” a Zalewem Wiślanym. Pas ów, zgodnie z postanowieniami traktatu pokojowego, objęty był całkowitym zakazem budowy fortyfikacji. Luka ta stwarzała potencjalną szansę na obejście nowych fortyfikacji i wykonanie bezpośredniego uderzenia na Królewiec. Rozwiązaniem okazało się wykorzystanie rzek Pasłęki i Łyny. Budowa systemu zapór m.in. w Pierzchałach, Stopkach, Frydlandzie i Welawie pozwoliła na podniesienie poziomu wód w rzekach i na bagnach, co docelowo w przypadku ich zniszczenia pozwalało zalać nizinną część okolic i tym samym zablokować ruch przeciwnika. Dodatkowo na północ od Pregoły w system wpięto „Pozycję Dejmy”, tj. pas umocnień z I wojny nad rzeką Dejmą ${ }^{44}$.

Do 1934 r. wybudowano łącznie ok. 300 schronów na odcinku od jez. Taftowo, przez Henrykowo, Runowo, Nową Wieś, Kiertyny, Judyty po Ostre Bardo i rzekę Łynę. Nową linię obrony tworzą punkty oporu złożone z 3-4 schronów przystosowanych do bocznego ognia karabinów maszynowych. Odpowiednia ich lokalizacja w terenie oraz gęsta sieć zasieków ułatwić miały obronę okrężną grupy. Z oszczędności stawiano głównie lekkie schrony betonowe dla 1 ciężkiego karabinu maszynowego wylane na blasze falistej. Z podobnych elementów budowano ukrycia i schrony bierne. Równolegle wznoszono także odporniejsze, żelbetonowe schrony piechoty, a także liczne obiekty obserwacyjne oraz konstrukcje nietypowe. Całość połączono siecią okopów, stanowisk artylerii polowej i ckm, a na leśnych odcinkach założono zasieki i tzw. potykacze ${ }^{45}$.

Ogniwem łączącym „Trójkąt Lidzbarski” z istniejącymi fortyfikacjami linii Jezior Mazurskich była pozycja Kanału Mazurskiego (Masurische Kanal-Stellung). Była to pozycja ryglowa o długości ok. $50 \mathrm{~km}$ rozciągająca się między jez. Mamry w okolicach Węgorzewa a Allenburgiem (Drużba), gdzie łączyła się z pozycją lidzbarską.

$* * *$

Okres Republiki Weimarskiej stanowi ciekawy przykład podejścia państwa, objętego międzynarodowymi ograniczeniami militarnymi, do kwestii budowy systemu bezpieczeństwa kraju. W planach tych Prusy Wschodnie odgrywały niezwykle doniosłą rolę. Przyczyny natury ideologiczno-historycznej oraz położenie prowincji czyniły z Prus Wschodnich obiekt zainteresowań tak niemieckich, jak polskich sztabowców. Oddzielone od reszty państwa morzem i tzw. „polskim korytarzem" Prusy Wschodnie musiały liczyć przede wszystkim na własny potencjał obronny. Stąd też stała troska o modernizację i rozbudowę istniejącego w prowincji systemu fortyfikacji stałych i polowych. Ta troska o potencjał

\footnotetext{
44 Trójkąt Lidzbarski, [w:] www.ostpreussen.prv.pl

45 Ibidem.
} 
obronny „bastionu wschodniopruskiego” nie była jednak wyłącznie determinowana strategią defensywną. W warstwie planistycznej dostrzegano wybitną rolę Prus Wschodnich w dziele wiązania części sił polskich, a przede wszystkim doceniano i uwzględniano w studiach sztabowych walory ofensywne w odniesieniu do możliwości opanowania Pomorza lub wyprowadzenia uderzenia tyły głównych sił polskich skoncentrowanych w pasie Wielkopolski i Pomorza.

\section{East Prussia in the military strategy of the Weimar Republic}

The period of the Weimar Republic constitutes an interesting example of the state's approach to the issue of building of the country's security, while being at the same time subject to international military restrictions. In this field East Prussia played a very important role. Reasons of ideological and historical nature as well as the location of the province, turned it into the object of interest of both German and Polish staff officers. Separated from the rest of the state by the sea and the so-called „Polish corridor”, East Prussia had to rely mainly on its own defensive potential. That is the reason of the permanent care for modernization and development of the existing system of stable and field fortifications. This concern with defensive potential of the „East Prussia bastion”, was not determined only by the defensive strategy. In the planning layer, the conspicuous role that East Prussia played in the engagement of Polish armed forces was noticed. Yet, above all, offensive values pertaining to the possibility of capturing of Pomerania or conducting attacks in the rear of the main Polish forces, concentrated in the belt of Great Poland and Pomerania, were appreciated. 